\title{
Comparative Analysis of Real Estate Bubble in China and Japan
}

\author{
Zhigang Wang \\ Zhuhai College of Jilin University \\ Zhuhai, China 519041
}

\begin{abstract}
Real estate investment has been growing rapidly and real estate prices rising steadily since the marketization of real estate in China. Many scholars have come to the conclusion that China's real estate industry has the phenomenon of bubble. We can find that there are some similarities between China and Japan and there are also obvious differences between them by contrasting with the development process of real estate bubble in Japan. There are many common features in China and Japan in the aspects of real estate investment, financial support and social speculation psychology; but there is a big difference between China and Japan in terms of interest rate policy, exchange rate policy, land system and national development stage. Therefore, although the governance of China's real estate bubble can draw lessons from Japan, more attention should be given to special national conditions. We should formulate relevant regulatory policies according to the local conditions.
\end{abstract}

Keywords - China and Japan; real estate bubble; comparative analysis

\section{INTRODUCTION}

Since 1998, China stops implementing housing distribution system and implements monetization of housing system gradually. The real estate industry has become one of the important pillar industries of China's national economy and made great contributions to the rapid growth of the national economy. But since 2003, China's real estate investment has risen sharply and real estate price also hit new highs. The real estate industry began to show signs of overheated market and industry bubble. Many scholars have made researches and elaborations for the bubble question of real estate industry in China, which dates back to 2005, Zhou Jingkui, Cao Zhenliang have proposed that there is an obvious real estate bubble in China's first tier cities and there is a real estate market overheating problem even from the nationwide. If the market risk can not be effectively controlled, the overheated real estate market may evolve into an overall bubble which will affect the whole country. Zeng Wuyi, Li Xiang (2011) made panel data analysis of the real estate prices of 35 large and medium-sized cities in China using mathematical analysis method and came to the conclusion that China's real estate industry had the phenomenon of bubble finally. Zhang Yushuang (2016) made an empirical analysis of real estate bubbles in China through index method, multiple linear regression method and local equilibrium method. He believed that China's real estate market bubble had reached a more serious extent and need to be regulated and guided. From the research results of the above scholars, the bubble problem of China's real estate market has been serious. The development process of the real estate bubble has certain reference significance to China considering the fact that Japan had experienced a very serious real estate bubble in the last 80 and 90 s of last century. This paper intends to compare and analyze the specific characteristics of the real estate bubble between China and Japan to facilitate the formulation and implementation of government regulation and control policies.

\section{SIMILARITIES OF REAL ESTATE BUBBLE IN CHINA AND JAPAN}

\section{A. Real Estate Investment Is Rising Rapidly}

In all the countries that have experienced real estate bubbles, there is almost a common feature--- the scale of real estate investment is huge and rising rapidly. Although from the perspective of national economic development, real estate investment is an essential part, if economic growth depends too much on real estate investment and makes it account for a large proportion in the national economy. It will lead to overheated industry development and unbalanced investment structure, and then lead to asset bubbles.

In 1970s, Japan's economy is growing fast among them, the growth rate of fixed asset investment is particularly rapid which has become an important factor to promote Japan's economic development. At the same time, the continued rise about national income has further stimulated the purchasing demand of real estate. Large amounts of capital have been pouring into the real estate market, seeking profits has become a historical necessity according to general economic logic. Related statistical data show that between 1974 and 1990, Japan's real estate investment accounted for $49.4 \%$ of the average proportion of fixed asset investment and the proportion of real estate investment in GDP also reached a historical peak of $10.76 \%$ in 1988 . In the following years, it remained at this level and far beyond the limits of the national economy

Compared with Japan, China's economic growth is more dependent on investment. In the case of insufficient domestic demand, China's economy depends on investment drive for a long time and the performance of the real estate industry is particularly evident. In 1998, China ended the welfare housing distribution system, started monetization housing distribution scheme completely and opened the golden age of China's 
commercial housing market. Real estate investment is increasing rapidly. Since 2004, the proportion of real estate investment in GDP has been maintained at a high level. Since 2009 , the proportion has been more than $10 \%$. In 2014, it reached a historical peak of $14.76 \%$. This value has gone far beyond the level when Japanese real estate bubble collapsed. This shows that China's real estate bubble has been in a very serious situation.

\section{B. The Financial Environment Is Too Loose}

The real estate industry is a typical capital intensive industry compared with other industries. It can not do without the support of financial institutions from real estate development to real estate consumption. This kind of support is mainly manifested in various types of development loans for real estate development enterprises and mainly manifested in real estate mortgage loan for property buyers. In fact, all previous domestic and foreign real estate bubbles are inseparable from the shadow of financial support. This kind of financial support shows the national expansionary monetary policy macroscopically and shows the strong support of bank credit microscopically. When the financial environment is too loose, the state is lack of constraint and regulation of financial support, the real estate bubble will be inevitable.

From the perspective of the growth of money supply, Japan's money supply grew by an average of $10.4 \%$ annually in 1986-1990 and shows 2.1 percentage points higher than 1981-1985 years. Show 8.3 percentage points higher than 1991-1995 years after the bubble burst. Japan carried out a very loose monetary policy and continued to cut the discount rate in order to promote economic development in this period. The 4 discount rate was reduced only in 1986. By the end of 1986, the discount rate had dropped to $3 \%$ and reduced 2 percentage points compared with the same period in 1985. On the other hand, from the perspective of credit growth, Japan's commercial banks and other financial institutions issued a large number of mortgage loans in order to benefit more from the hot real estate market. According to the statistics, real estate mortgage loans in Japan accounted for $17 \%$ of the national bank loan balance in 1984. To 1992, the proportion has risen to $35.5 \%$.

For China, the problem of the rapid growth of money supply may be more serious than Japan. Since 2004, the growth rate of China's money supply is above $12 \%$. Among them, the growth rate of money supply has reached a historical high of $28.5 \%$ in 2009 in order to get rid of the impact of the international financial crisis and stimulate economic growth. Then although it came back down, the growth rate of China's money supply is still far above normal considering the economic growth rate and inflation rate. In fact, currency over issue problem has become one of the important reasons why asset bubbles are difficult to govern in China. On the other hand, the development of China's real estate industry relies heavily on the support of financial institutions such as banks. In the current capital chain of the real estate market in China, commercial banks participate almost all the time from real estate development to final product consumption. In the case of house prices climbing steadily, both the real estate development enterprises and the property buyers are high on
"Leverage". This greatly increases the risk of the real estate bubble burst.

\section{To Form Social Speculative Psychology Accelerately}

According to the basic view of Marx's political economy, there is a basic law of value in the change of commodity prices, namely, commodity prices are determined by commodity value and fluctuate around the value. As a commodity, the price of real estate should conform to this basic law. But the irrational phenomenon of inflated real estate prices often occurs affected by the "expected" factors. In reality, real estate price volatility is a very normal phenomenon. But it is easy to form an expectation that there is only increase but no decline about price. This expectation will lead to that real estate demand shifts from consumer demand to speculative demand. When some speculators begin to benefit, more intense social speculative psychology will be further triggered. Once this social atmosphere has been formed, it is expected to be difficult to break. The governance of the real estate bubble will also become extremely difficult.

Japan has a small territory and a large population. Per capita living space ranks backward among developed countries. Japan has achieved rapid economic growth, advanced industrialization and urbanization rapidly after World War II. This further highlights the scarcity of land resources in Japan. Even in Japan, the basic idea of priceless land was formed in the hearts of the Japanese people. In fact, Japan's land prices have also risen all the way and further strengthened the psychological expectation of Japanese people from the Second World War to the early 1990s. Japan Statistics Bureau data show that the average street price index rose from 70.7 to 147.8 in Japan (In 2000, the index was 100) in 1980-1991 years. Among them, land prices increased to $14.1 \%$ in 1990. In this period, the psychological expectations of Japanese residents and the crazy rise of land prices have been proved to support each other. This triggered a very fanatical social speculative mentality and the herding effect began to appear. Whether business or ordinary residents all have followed up and invest a lot of money in land and real estate. And then gave birth to the biggest real estate bubble in Japan's history.

The same thing also happened in China and it's still going on for now. Although China has a larger land area compared with Japan, the population is bigger. What is more, most of the western region is not suitable for habitation. So, from the per capita land resources, China is no more optimistic than Japan. Since the real estate industry has been identified as a pillar industry, the central government has given policy support. Local governments also spared all effort to develop the real estate industry based on considerations about "Land finance". In addition, China is still in the process of rapid urbanization and industrialization and the demand for land and real estate is huge. As a whole, the supply and marketing of the real estate market is booming. However, in the process, the demand for the aircraft was gradually started. Especially in the case of narrow investment channels for Chinese residents, investment in real estate has become the first choice for many residents. This also triggered a social speculative unrest in China, which lead to the rising steadily of land prices and house prices. China statistical yearbook data show that in 2006, the average 
land acquisition price of China's real estate development enterprises was only 907.2 yuan/square meter. By 2016, it rose to 3341.2 yuan/square meter. China's average land purchase price has risen nearly 4 times in ten years, and among them, the land price growth rate reached $31.5 \%$ in 2009 . In the face of such astonishing price growth, no one can remain unmoved. The whole society was plunged into an irrational state. A large number of enterprises and individuals are involved in real estate speculation and the real estate bubble is becoming more and more serious.

\section{THE MAIN DIFFERENCES BETWEEN CHINA AND JAPAN IN THE REAL ESTATE BUBBLE}

\section{A. Interest Rate Policy Is Different}

Throughout the development of Japan's real estate bubble, its improper interest rate policy was the main factor that led to the ultimate bubble collapse. In 1980s, Japan's domestic and international economic environment has changed dramatically. There are some difficulties in economic development. But the Japanese government has not chose the right macroeconomic policy and the old method is still used to deal with the new problems. The Japanese central bank has lowered official interest rates for the 5 times in a row in 1986-1987 years in order to stimulate economic development. Reduced official interest rates from $5 \%$ to $2.5 \%$ and decreasing amplitude is $50 \%$. In 1987, after Japan's economic situation improved, there was no timely return to interest rate. Japan failed keeping interest rates low for 27 months. Loose interest rate policies have greatly stimulated the speculative psychology of consumers and the real estate bubble continued to expand. To 1989, the Japanese government felt the pressure of the bubble eventually and started to raise interest rates. But the speed is too high and the intensity is too strong. The official interest rate rose from $2.5 \%$ to $6 \%$ in one year and decreasing amplitude was more than one time. Such a radical interest rate policy has created a severe panic in the market. Investors stampeded for the exits one after another. The real estate bubble began to collapse.

Different from Japan, The Chinese government has been more cautious in its macroeconomic policy application. The interest rate adjustment also mostly adopts small fine adjustment mode and the policy effect was extremely mild. Loan interest rate data released by the Central Bank of China show that before September 16, 2008, there are 10 rate hikes. The aim is to curb economic overheating and prevent asset bubbles. The international financial crisis happened in 2008 and China begins the cutting interest rate channel to stimulate economic development. Until October 2010, China started a new round of interest rate hike and continued to curb economic overheating. From July 2011 to now, Chinese economy begins to enter the new normal and the growth rate has slowed down due to the European debt crisis and the structural transformation of the domestic economy. The Central Bank has steadily implemented interest rate reduction policy in order to achieve stable transformation and upgrading. Reduction of interest is a helpless behavior in consideration of the overall economic situation of the country, although this exacerbated the speculative sentiment in the real estate market to a certain extent.

\section{B. Exchange Rate Policies Are Obviously Different}

Japan has imposed a 22-year policy of fixed and low exchange rates after the end of World War II. Japanese companies in this period do not need worry about exchange rate fluctuations and concentrate on the production and export of products. Japanese economy was advancing by leaps and bounds. But at the same time, Japan's trade surplus was growing and it also caused discontent in the western countries led by the United States. Thus, exchange rate reform was started in Japan and the appreciation of the yen was on the agenda. December 1971, the "Smithsonian Agreement" was reached at the meeting of finance ministers of ten western countries. Japan promised to change from fixed exchange rate regime to floating exchange rate regime and agreed that the yen appreciated by $16.88 \%$ and at this point, the yen traded at 308:1 against the dollar. The rise of the yen kicked off. However, the appreciation of the yen has not fundamentally changed the trend of Japan's trade surplus. February 1973, the United States announced that the dollar depreciated $10 \%$ against gold. Japan promised to continue to float over the exchange rate system. The yen continued to appreciate, but the appreciation was relatively manageable. To 1985, the yen has appreciated to 240-250 yen against the floating exchange rate of \$1. In 1985, the famous "Plaza Agreement" was signed and Yen appreciation suddenly accelerated. The exchange rate Yen against dollar rose from 250:1 to 120:1 in early 1988 swiftly. To 1995, the exchange rate Yen against dollar rising to historic 80:1. Due to the rapid appreciation of the yen, hot money around the world enters the Japanese real estate market. The real estate bubble is expanding rapidly.

In June 2010, China restarted the exchange rate reform and so far has expanded the floating range of RMB exchange rate for several times. But China bears a prudent attitude towards people's free exchange. This is the third phase of the appreciation of RMB. Since the exchange rate reform in 2005, the appreciation of RMB is obvious. Yet in the eight years until 2012, the total range of appreciation only has $21.9 \%$. After 2012, influenced by slowing growth rapid of China's economy and raised interest rate of dollars, the RMB appreciation expectation has started to weaken. So far since 2014, RMB even has depreciated to some extent. From the above data, it can be seen that the speed of RMB appreciation is relatively slow, which is different from the increase rate $50 \%$ of yen from 1985 to 1988 . China's policy of exchange rate is much more prudent, which greatly reduces the speculative action of foreign funds and has a positive effect on the steady development of China's real estate market.

For China, The appreciation pressure of RMB also exists because of the sustained strong economic growth and trade surplus is expanding year by year. But in terms of exchange rate policy, China's practice is quite different from Japan's. China has adopted a policy of small and gradual appreciation in order to prevent the excessive appreciation of RMB caused by the impact of international hot money. In 1994-1998, China's RMB foreign exchange official market and swap market were merged and the RMB began to appreciate 
gradually. During this period, the cumulative appreciation rate is 5\% and this is the first stage of RMB appreciation. In July 21,2005 , China began to reform its exchange rate system and gave up the traditional practice of pegging to the dollar and changed into the exchange rate system that based on market supply and demand, referenced to a basket of currencies and with administration. But RMB freely exchanged to foreign currency is still not allowed. This is completely different from Japan's policy in those years. Under the background of the implementation of the new system, in 2005-2008 years, the RMB exchange rate has appreciated by $21 \%$. This is the second stage of RMB appreciation. In July 2008, affected by the international financial crisis, China actually pegged the exchange rate that RMB against dollar at the level of 6.83:1. In the following two years, it's basically the same. In June 2010

\section{The Land System Is So Different}

Compared with other commodities, real estate commodity has the immobility. The reason is that real estate is essentially a combination of real estate and real estate and this is one of the most distinctive features of real estate. Considering from the aspect, the price of the real estate should include two parts: the price of the building on the ground and the price of land. In the process of real estate commodity production

As a typical capitalist country, Japan's land is of private property right and there is no national centralized control of land supply. Thus the real estate enterprise's obtaining of land is a simple market trade which is of high efficiency. On the other hand, as the second largest economy in the world after World War Two, Japan is already a developed country. It does not have urban and rural dualistic division structure in land market. This integrated land market makes the land supply more free and the circulation is convenient too. And it is also because of this, during the bubble period of Japan's real estate in the last century, the supply of real estate could increase quickly under the command of the market's need. The increased supply not only had commercial houses developed by real estate enterprises but also had self-built houses for ordinary citizens, which restricted the real estate prices to a certain degree. Meanwhile as the main market participants were entities or individuals, the subsequent problems such as debt settlement could be solved through the market after the bubble exploded in Japan's real estate, which did not bring large loses to the national asset and the government's finance and therefore had a positive influence on the recovering of Japan's economy.

By comparison, China's land is of national property right. And the land supply lacks various channels. The nation has centralized control of the primary land market. The land trade implements the system of "bidding, auctioning, listing" whose procedure is rather complicated and the efficiency needs to be improved. Besides, since China has had urban-rural dual structure for a long period, the rural collective land cannot be circulated freely and must enter into the land market through national expropriation. Yet the expropriation and transfer have high cost and low efficiency, which forms the bottleneck of land supply. At the same time, large quantities of people's selfbuilt houses with limited property rights are unable to enter into the real estate market, therefore the market need cannot be satisfied. This further intensifies land's restrictions on real estate market. What's more, since the reform of tax-sharing system in China, the finance of local governments has been depending on land-transferring fees extremely. Once the bubble of real estate explodes, it will definitely cause sharp decrease in local finance and many local governments will fall in financial crisis. In order to protect benefits, local governments surely will control the amount of land supply more strictly. The effective governance of bubbles in real estate is tough to achieve.

\section{Different Urbanization Process}

In the period of developing economy and society, the urbanization process has profound influences on one country's real estate industry. Normally, with the deepening of urbanization large population will come into cites and thus trigger larger needs in real estate market. After World War Two, Japan not only achieved an economic take-off but also built a historical record of fast urbanization. During 1947-1965, the urbanization rate of Japan increased from $33.1 \%$ to $68.1 \%$ with an average annual growth of $1.94 \%$, which means that there were 2.28 million people entering into cities from rural areas. In 1975, the urbanization of Japan is $75.9 \%$, to 1985 the promotion of urban population in Japan reached $76.6 \%$. It can be said that Japan had completed urbanization. From the data we can see that in 1975-1985, Japan's urbanization rate only improved $0.8 \%$ which means that the urban population during this period was steady and the urbanization process had ended. Under such circumstances, the rigid demand of Japan's citizens on housing basically had been all emitted. There was limited space to improve. Therefore we can judge that the high housing prices in Japan at that time lacked effective demand support. The real estate market was totally in a faked prosperous status caused by speculative capital. Once the housing price reached to the top, the entire market would be unmanned and the housing price would plummet quickly. The broken of bubbles would be unavoidable.

However, the current status of China is totally different. Since the in 1978, though the urbanization level of China has been increasing rapidly, it's still at a rather low level. Data has shown that in 1978, the urbanization rate of China was $17.92 \%$. To the year 2015, the ratio of urbanization in China had reached $56.1 \%$ which had raised nearly $40 \%$. Yet when compared to the urbanization rate of $80 \%$ in developed countries, we are still at a low level, which means that the urbanization process in China sill has a long way to go. Seeing from the developing strategy of the whole country, China will reach the level of developed countries in the middle of Twenty-first century. At that time the level of urbanization will reach to the level of developed countries with no doubts. The rate will increase at least $20 \%$ when compared to that of 2016. Under such circumstances, it definitely will push continuous expand of housing needs. This rigid demand will neutralize the bubbles in the real estate market to a large extent. From this point, we can say that the governance of bubbles in China's real estate market is more optimistic than that of Japan back then since there's the support of long-term rigid demand. 


\section{CONCLUSION}

From the perspective of history, Japan's real estate bubble burst is an inevitable result from gradual accumulation. After a long period of rapid economic development in the last century, the yen is under pressure to appreciate. However, the Japanese government has made a wrong decision for the exchange rate policy. At the same time, loose financial policy and tax system is also an important cause of Japan's real estate bubble. What is more, popular speculative psychology and radical government regulation measures eventually led to the collapse of the real estate bubble and Japan's economy has been battered gravely.

Through the comparative analysis of China and Japan real estate bubble, we found a certain degree of similarity between the two countries' real estate market, namely excessive reliance on real estate development investment, the deep involvement of financial institutions in real estate industry and fanatical social speculative psychology. All this shows that there is a crisis in China's real estate market and we need to be vigilant. But on the other hand, there is a huge difference between the real estate markets in the two countries. First, there are significant differences between interest rate and exchange rate policies. So far, China has implemented strong interest rate intervention and foreign exchange control, so that the appreciation of the RMB is controllable. It is entirely possible to avoid the historical tragedy of the yen's rapid rise in the short term. The real estate market will not be subjected to the strong impact of interest rate and exchange rate fluctuations; Secondly, the development stage of the two countries is different. At present, China's economy is in the transformation stage, and there are still significant advantages. The process of urbanization is still advancing rapidly. The effective demand of the real estate market is huge. Therefore, there are risks in China's real estate bubble, and it is unlikely to collapse as quickly as the Japanese housing market. But the government must start early and take measures to control the bubble in consideration of the huge volume of China. Otherwise, if the housing bubble bursts, the damage to China's economy will be far greater than Japan's.

\section{REFERENCES}

[1] Zeng Wuyi, Li Xiang. Research on the test and cause mechanism of the price bubble in China's real estate market [J]. The Journal of Quantitative \& Technical Economics, 2011(1): 140-151.

[2] Zhang Yushung. Measurement of real estate price bubbles in China [J]. Statistics and Decision, 2016(5): 129-132.

[3] Zhou Jingkui, Cao Zhenliang. China's real estate bubble and non bubble-An empirical analysis based on speculative theory[J]. Journal of shanxi finance and economics university, 2004(1): 53-57.

[4] Jiang Chunhai. Empirical analysis of speculative bubbles in China's real estate market [J]. Running the World, 2005(12): 71-83.

[5] San Feng. China's asset price inflation and Japan's bubble economy: comparison and Enlightenment $[\mathrm{J}]$. Contemporary Economy of Japan, 2008(1): 28-33.

[6] Zheng Rongqing. Research on the bubble degree of China's current real estate market Comparative analysis based on international data[J]. contemporary economics, 2016(22): 4-6.

[7] Zhao Qianqian, Wang Hong. Analysis of the causes of Japan's real estate bubble and its reference to China[J]. China's Real Estate Finance, 2003(5): 42-46 